\title{
LITTLE KNOWN HOMERIAN (LOWER SILURIAN) GRAPTOLITES FROM KOSOV QUARRY NEAR BEROUN, THE CZECH REPUBLIC
}

\author{
PETR ŠTORCH ${ }^{1, *}$, ŠTĚPÁN MANDA² \\ 'Institute of Geology of the Czech Academy of Sciences, v.v.i., Rozvojová 269, 16500 Praha 6, the Czech Republic; e-mail: storch@gli.cas.cz. \\ ${ }^{2}$ Czech Geological Survey, Klárov 3, 11821 Praha 1, the Czech Republic; e-mail: stepan.manda@geology.cz. \\ ${ }^{*}$ corresponding author
}

Štorch, P., Manda, Š. (2019): Little known Homerian (lower Silurian) graptolites from Kosov quarry near Beroun, the Czech Republic. - Fossil Imprint, 75(1): 44-58, Praha. ISSN 2533-4050 (print), ISSN 2533-4069 (on-line).

\begin{abstract}
The Homerian graptolite fauna of the upper Cyrtograptus lundgreni and lower Colonograptus ludensis-Colonograptus gerhardi biozones, recovered from densely sampled sections in Kosov quarry includes several poorly known species, which appear to be useful in high resolution correlation. Gothograptus kozlowskii, Gothograptus aff. domeyki, Semigothograptus meganassa, Pristiograptus auctus, Monograptus ambiguus, Monograptus subflexilis and Cyrtograptus hemmanni are described and discussed in detail with reference to their stratigraphic range and palaeogeographic distribution which indicates close links between the Homerian graptolite faunas of Baltica, Avalonia and peri-Gondwanan Europe.
\end{abstract}

Key words: graptolite taxa, upper Wenlock, Silurian, biostratigraphy, palaeobiogeography, Prague Synform

Received: February 25, 2019 | Accepted: June 6, 2019 | Issued: August 29, 2019

\section{Introduction}

The seven graptolite species described in this paper form part of a large graptolite fauna obtained from bed-by-bed collecting through a middle and upper Homerian shaly offshore succession within the Prague Synform, exposed in the Kosov quarry near Beroun. A multiproxy study of the Kosov section carried out by Manda et al. (2019) focused on faunal changes and the sedimentary and carbon isotope records across the middle Homerian lundgreni mass extinction event, and subsequent late Homerian recovery interval. This paper aims to provide a palaeontological supplement devoted to the systematic description of less well-known graptolite species recorded in the Kosov section, their palaeogeographic distribution and biostratigraphic significance. Gothograptus kozlowskii KozŁowsKa-DAwidzIUK, 1990, Gothograptus aff. domeyki KozŁowsKA et al., 2019, Pristiograptus auctus RicKARDS, 1965, Monograptus ambiguus JAEGER, 1991, and Cyrtograptus hemmanni BoučEK, 1934 are recorded for the first time in the Czech Republic. Semigothograptus meganassa (RickARDS et PALMER, 2002) represents an unexpected, stratigraphically lowest record of the species, which calls its derivation from $G$. nassa considered by Kozłowska (2016) into question. Monograptus subflexilis PřıBYL, 1941 was previously an insufficiently described species with no diagnosis, incorrectly referred by Teller (1986) to Monograptus flemingii (SALTER, 1852).

\section{Geological setting}

The abandoned Kosov quarry, located on the SW slope of Holý Vršek hill about 2.75 km SSW of the Beroun train station (Text-fig. 1), is the largest and most complete Silurian exposure in the Lower Palaeozoic of central Bohemia, known in geological literature as part of the Barrandian area. The quarry consists of six levels, covering 160,000 square meters, and exposing a Silurian sedimentary and volcanic succession ranging from middle Sheinwoodian black shales of the Monograptus belophorus graptolite Biozone through to middle Pŕídolí platy limestones and marly shales of the Monograptus bouceki Biozone. Western (,new quarry“) and eastern (,old quarry”) parts of the quarry are separated by a narrow rock crest retaining part of the original surface relief.

Homerian strata exposed in the lowest, $6^{\text {th }}$ and $5^{\text {th }}$ levels of the new quarry (section Kosov 767 in Krríž 1992) are overlain by a massive succession of basaltic pillow lavas, hyaloclastites, volcanic agglomerates and tuffs. The middle part of this section was measured and described by Turek (1983, 1990), who studied also the faunal content, including the graptolite record and biostratigraphy.

The herein described section Kosov 2 (Text-fig. 2; GPS coordinates $\left.49^{\circ} 56^{\prime} 22.38^{\prime \prime} \mathrm{N}, 14^{\circ} 3^{\prime} 10.98^{\prime \prime} \mathrm{E}\right)$ at the $5^{\text {th }}$ level of the quarry begins 5 meters above the stratigraphically highest basalt sill intruded in black shales of the lundgreni Biozone, and continues higher up on the NNW wall. Section 


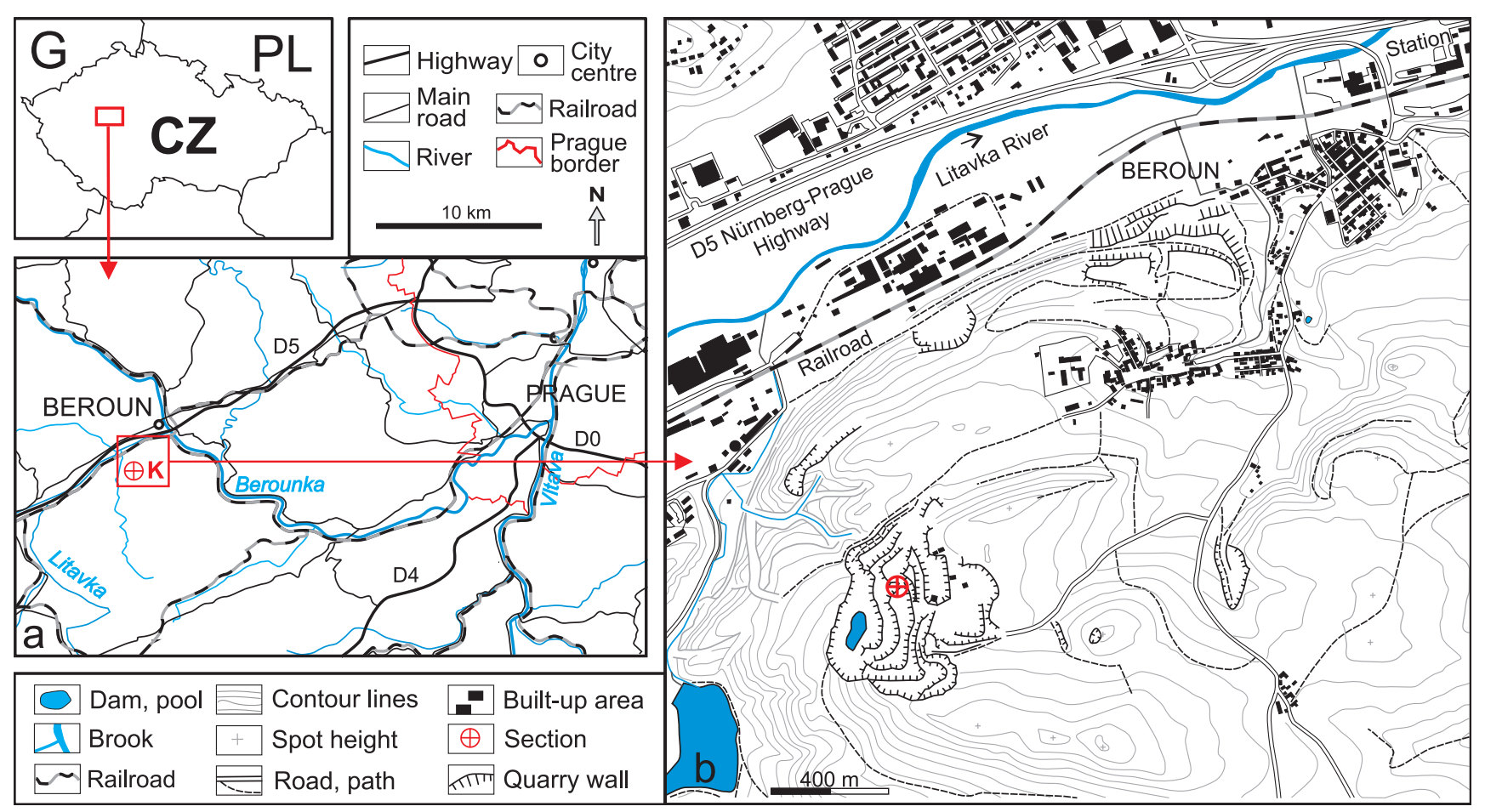

Text-fig. 1. Location of the Kosov quarry section within the Czech Republic and on a detailed topographical map.

Kosov 1 (Text-fig. 3; GPS coordinates 4956'21.85"N, $\left.14^{\circ} 3^{\prime} 11.77^{\prime \prime} \mathrm{E}\right)$ is exposed on an isolated rock wall about 30 meters east of Kosov 2.

\section{Description of the sedimentary succession}

Black, calcareous, laminated shales with tuffitic intercalations form the lower, about $440 \mathrm{~cm}$ thick, part of the Kosov 2 section (Text-fig. 2). Thin laminae of palecoloured tuffitic material are common. Some bedding planes are covered with anhydrite and iron oxides/hydroxides derived from decomposed pyrite. Thin beds of grey, planarlaminated tuffites and yellow tuffites are common throughout the shale succession, both fine-grained and for the most part replaced by fibrous calcite. Tuffite beds are $2-4 \mathrm{~cm}$ thick. The thickness may vary also due to local shallow channellike depressions at the base of some tuffites; the distance between individual tuffite beds is $6-40 \mathrm{~cm}$. Muddy limestone nodules (max. $60 \mathrm{~cm}$ in diameter) with convolute lamination, cephalopod fragments and ostracods appear in the upper part of the studied shale. A shale interval $15 \mathrm{~cm}$ thick (sample $\mathrm{K} 2 / 10$ ) contains numerous small nodules of dark-grey to black muddy limestone, rich in pyrite (with max. diameter $10 \mathrm{~cm}$ ) and occasional 3D-preserved cephalopod shells filled by muddy limestone and sparitic calcite. An interval with common nodules of grey muddy limestone with ostracods and cephalopod fragments (sample K2/5) lies within a prominent coarse-grained, yellow tuffite bed. Occasional small limestone nodules occur within other tuffite beds.

The section continues with black laminated shale (K2/2) followed by a $12 \mathrm{~cm}$ thick interval, in which tuffites and argillitic limestones alternate (K2: interval between samples 1 and 2). The lower part of the interval forms a 4-14 cm thick bed (above marker horizon 1; Text-fig. 2) of yellow coarse-grained tuffite, including small diagenetic nodules of light-coloured tuffitic limestone with abundant minute fossils, mostly gastropods, cephalopods and ostracods. The tuffite contains abundant fragments of crinoids, cephalopods, brachiopods, gastropods, bryozoans and others.

Just above the tuffite, a $4-12 \mathrm{~cm}$ thick bed of rustygrey argillitic shelly limestone rich in pyrite and thin accumulations of flattened brachiopod shells is developed (between marker horizons 2 and 3 in Text-fig. 2). The section continues with a $28 \mathrm{~cm}$ thick blue-grey shale with Chondrites-type burrows (sample K2/1), including common fragments of algae and minute pyrite nodules. A $1 \mathrm{~cm}$ thick bed of yellow fine-grained tuffite is developed $13 \mathrm{~cm}$ above the base of the shale. The burrowed shale is overlain by a 6 $\mathrm{cm}$ thick laminated grey tuffite.

Higher up is a $50 \mathrm{~cm}$ thick black shale $(\mathrm{K} 1 / 1,2)$, incorporating a few thin beds of light grey tuffites with abundant nodules of light-grey mudstone which contain thin accumulations of skeletal material and occasional cephalopods, usually represented by fragments, less commonly by an incomplete small shell.

The Kosov 1 section (Text-fig. 2) continues with a 570 $\mathrm{cm}$ thick shale-dominated succession (samples K1/3-28). Black laminated calcareous shale prevails; light coloured laminae are rare. Small nodules of mudstone are abundant in sample K1/26. Black shale is confined to four $13-60 \mathrm{~cm}$ thick intervals, alternating with grey, calcareous laminated shale containing abundant fine-grained skeletal particles (brachiopods, trilobites, ostracods, cephalopods). The shale interval incorporates also several up to $10 \mathrm{~cm}$ thick beds of grey coarsely laminated tuffites (sometimes with a mass occurrence of WSW-ENE oriented graptolites at the base) and three beds of yellow-grey tuffites. Three 3-9 cm thick beds of grey clay and coarsely laminated limestones containing abundant brachiopods and trilobites were also observed (samples K1/16, 20, 22). 


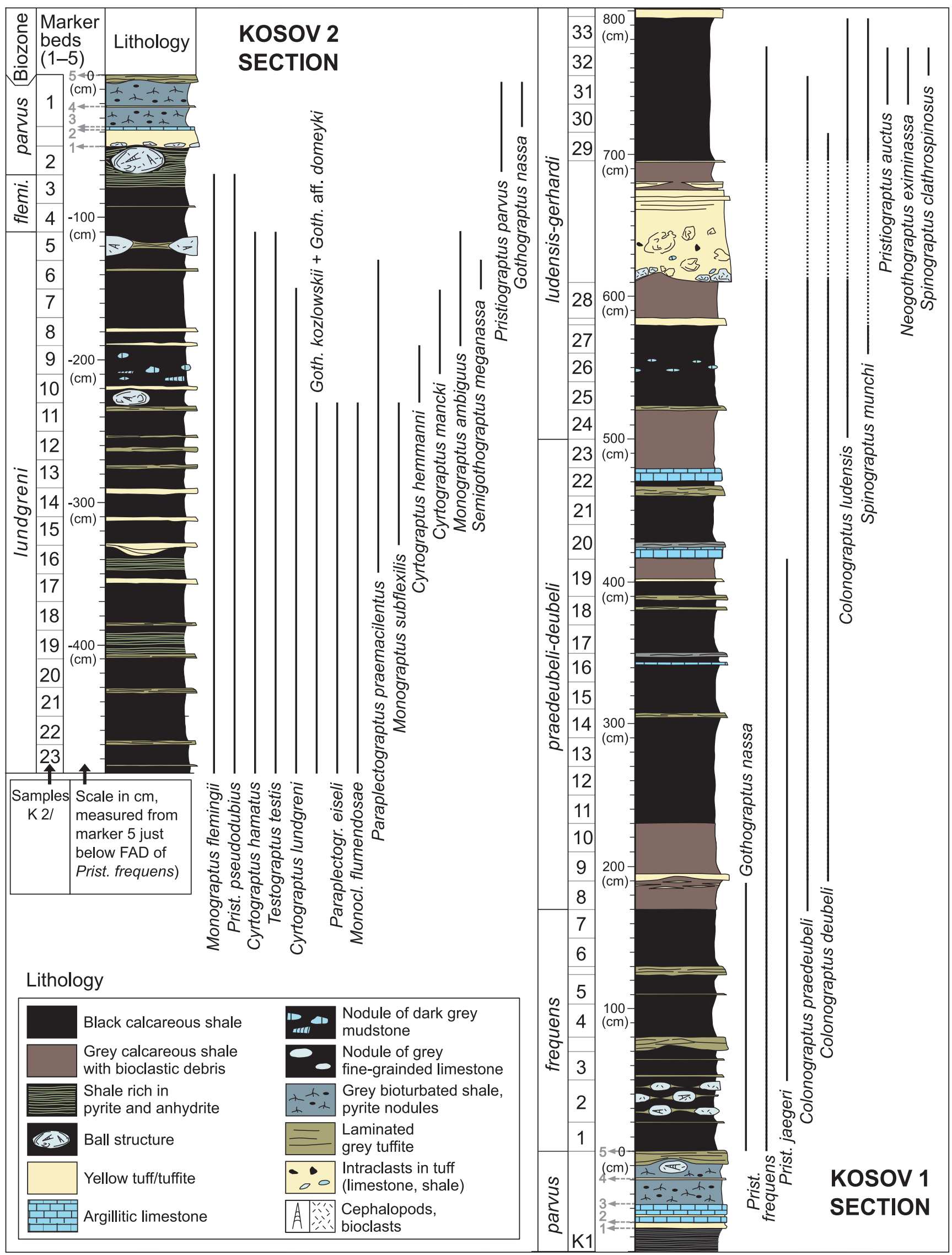

Text-fig. 2. Graptolite stratigraphic ranges in the middle - upper Homerian sedimentary succession of the two sections exposed in the Kosov quarry (modified from Manda et al. 2019). Abbreviations: Goth. - Gothograptus, Monocl. - Monoclimacis, Paraplectogr. Paraplectograptus, Prist. - Pristiograptus. Gothograptus kozlowskii and Goth. aff. domeyki exhibit identical stratigraphic range, and the two species are difficult to tell apart in less well-preserved specimens. 
Higher-up, a 50-65 cm thick yellow tuffite is developed (K1: interval between samples 28 and 29). The tuffite contains small rounded intraclasts of muddy limestone and shale, and slumped balls of cohesive skeletal muddy limestone and coarse pyroclasts in the lower part. Horizontal lamination and a thin, diagenetically more cemented interval are developed in the uppermost part of the tuffite bed. An erosional relief at the base of the tuffite reached at least $70 \mathrm{~cm}$ in height, and formed a prominent unconformity. Shale developed just above the tuffite contains both tuffitic admixture and thin local tuffite channel fills.

\section{Material and methods}

A series of 56 bulk samples, each about 0.03 cubic meter in volume, collected from the $13 \mathrm{~m}$ thick shale-dominated section yielded 2,582 determinable graptolites, but relatively few that were well-preserved and suitable for detailed measurements. All rhabdosomes are simply flattened in brown-grey, more or less bleached calcareous black shale, without significant effects of tectonic strain. Characters measured on graptolite rhabdosomes correspond with those employed by Štorch et al. (2011: fig. 13) and Štorch and Melchin (2018: fig. 3).

Illustrated and measured specimens from the Kosov sections prefixed by PŠ are housed in the collection of
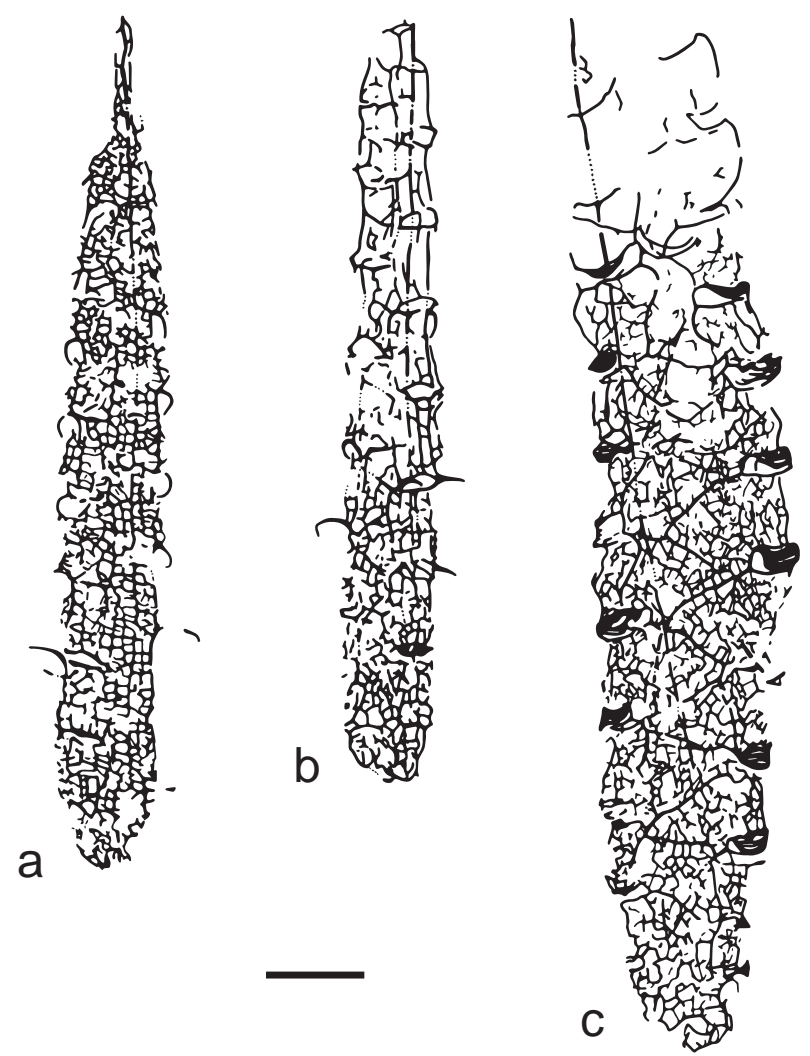

Text-fig. 3. Retiolitid graptolites from the upper lundgreni Biozone of the Kosov section. a, b - Gothograptus kozlowskii KozıowsKa-DAwIDZIUK, 1990: a - PŠ 3870, finite rhabdosome with curved apertural spines from sample K2/13; b - PŠ 3878, sample K2/11. c - Semigothograptus meganassa (RICKARDS et Palmer, 2002): PŠ 3863, non-finite rhabdosome with free nema, sample K2/6. All specimens $\times 10$, scale bar $1 \mathrm{~mm}$.
Petr Štorch in the Czech Geological Survey, Prague. Type specimens from the collections of the National Museum, Prague have numbers prefixed by NM-L; a specimen from the collection of Barrie Rickards at the University of Hull has its number prefixed by HUR; a specimen from the collections of the Museum für Natürkunde, Berlin has its number prefixed by $\mathrm{MBg}$; the prefix SX indicates the collections of the Sedgwick Museum, Cambridge and the prefix ZPAL is for a specimen housed in the Institute of Palaeobiology of the Polish Academy of Sciences, Warsaw.

\author{
Abbreviations \\ 2TRD - two thecae repeat distance \\ DVW - dorso-ventral width of the rhabdosome \\ th - theca \\ $\mathrm{M}$ - mean value \\ $\mathrm{n}-$ number of measured specimens.
}

\section{Systematic palaeontology}

\section{Genus Gothograptus FreCH, 1897}

\section{Gothograptus kozlowskii KozıowskA-DAWIDZIUK, 1990} Text-figs 3a-b, 4d-f

1990 Gothograptus (Gothograptus) kozlowskii sp. n.; Kozłowska-Dawidziuk, pp. 197-200, text-figs 3a-f, 4a-e, pl. 23, figs 1-4, pl. 24, fig. 3 .

2010 Gothograptus kozlowskii KozŁowsKA-DAwidzIUK; Loydell et al., fig. 4h.

2015 Gothograptus kozlowskii KozŁowsKa-DAwIDzIUK; Kozłowska, fig. 1A.

2019 Gothograptus kozlowskii KozŁowsKa-DAwIDZIUK; Manda et al., figs $7 \mathrm{~g}, 10 \mathrm{~b}$.

Holotype. Specimen no ZPAL G.XIII/43 from a Baltic erratic boulder from Jarosławiec, Poland, figured by Kozłowska-Dawidziuk (1990: pl. 24, fig. 3).

Material. More than one hundred flattened, mostly complete rhabdosomes from the upper lundgreni Biozone of the Kosov 2 section (samples K2/23-K2/11; see Manda et al. 2019: fig. 2).

\section{D i a g n o s i s . See Kozłowska-Dawidziuk (1990).}

Description. Rhabdosome comprises 9-12 pairs of thecae in mature, up to $12.6 \mathrm{~mm}$ long specimens with finite development. Many specimens, however, do not attain this length and full maturity. Rounded proximal end is $0.85-0.99 \mathrm{~mm}$ wide $(\mathrm{M}=0.92 \mathrm{~mm}, \mathrm{n}=11)$ at the level of the first thecal apertures. The rhabdosome is parallel-sided until about the level of the fifth thecal pair, with a mean width of $0.91 \mathrm{~mm}$ excluding spines $(\mathrm{n}=11)$, then gradually narrows in the distal part, which is terminated by a welldeveloped $0.15 \mathrm{~mm}$ wide and up to $1.6 \mathrm{~mm}$ long appendix. 2TRD increases from $1.45-1.68 \mathrm{~mm}(\mathrm{M}=1.55 \mathrm{~mm}, \mathrm{n}=$ 11) at th2 to $1.7-1.9 \mathrm{~mm}(\mathrm{M}=1.77 \mathrm{~mm}, \mathrm{n}=10)$ in the middle part of the rhabdosome, and decreases to $1.3 \mathrm{~mm}$ in the somewhat dwarfed distal-most thecae. Reticulum is dense and prominent in mature specimens. Clathria are regular and easy to recognize in juvenile rhabdosomes, but some clathrial structures become less distinctive in mature 
and heavily reticulated specimens. Nema incorporated in the lateral wall continues through the whole rhabdosome, up through the appendix. Thecal apertures bear $0.21-0.3$ $\mathrm{mm}$ long, ventrally or ventro-proximally projected clawlike lateral spines with a triangular base. The spines are thin, without a massive base in juvenile specimens.

Remarks. The present material matches most parameters and characters documented in the original description of the species (Kozłowska-Dawidziuk 1990), which was based upon chemically isolated specimens from an erratic boulder. Flattened finite rhabdosomes from the Kosov 2 section attain significantly greater maximum length (12.6 mm compared to $9.9 \mathrm{~mm}$ recorded in a single finite specimen from the type collection), and accordingly consist of a greater number of thecae (9-12 compared to 8 thecae reported in finite rhabdosomes of G. kozlowskii by Kozłowska et al. (2019)). The maximum width of the Kosov 2 specimens $(0.99 \mathrm{~mm})$ is less than the $1.24 \mathrm{~mm}$ recorded in the type material. Thecal spacing is denser in Kosov specimens, the well-developed reticulum and relatively thin clathrial lists correspond in the present and type specimens. Paired, claw-like curved apertural spines with broadened bases are typically developed and preserved in many rhabdosomes from the Kosov collection. The absence of the apertural spines or loops in some specimens may be a result of insufficient preservation, but a number of well-preserved finite rhabdosomes with thickened lips and obvious absence of any genicular and apertural structures in most thecae belong to a different taxon - Gothograptus aff. domeyki KozıowsKa et al., 2019. The present record of two gothograptids (species of the genus Gothograptus) in the upper lundgreni Biozone of the Kosov section is a significant contribution to palaeobiogeographic links and intrazonal correlation of this interval between peri-Gondwanan Europe and Baltica (Jeppsson and Calner 2003, Manda et al. 2019).

\section{Gothograptus aff. domeyki KozlowsKA, BATES, ZalasiewicZ et RadzevičIus, 2019 Text-fig. $4 \mathrm{a}-\mathrm{c}$}

1952 Gothograptus nassa (HoLm, 1890); Bouček and Münch, pp. 11-15, fig. 2a-i, (non 3a-d), pl. 1, figs 9-11.

aff. 2019 Gothograptus domeyki n. sp.; Kozłowska et al., figs 7g, $10 \mathrm{~b}$.

Material. More than one hundred flattened, more or less complete rhabdosomes from the upper lundgreni Biozone of the Kosov 2 section (samples K2/23-K2/11; see Manda et al. 2019: fig. 2).

Description. Mature, up to $11.8 \mathrm{~mm}$ long rhabdosome has 10-12 pairs of thecae and well-developed appendix. The rhabdosome is $1.05-1.22 \mathrm{~mm}$ wide $(\mathrm{M}=1.1$ $\mathrm{mm}, \mathrm{n}=14$ ) in its parallel-sided proximal and mesial part, then slowly tapers to $0.35-0.43 \mathrm{~mm}$ just below the appendix. 2TRD increases from $1.54-1.6 \mathrm{~mm}$ at th2 $(\mathrm{M}=1.56 \mathrm{~mm}$, $\mathrm{n}=12)$ to $1.7-1.75 \mathrm{~mm}(\mathrm{M}=1.73, \mathrm{n}=14)$ in th5-6. Small but distinct genicular hoods of nassa-type are developed on the first and, in some specimens also second (Text-fig. 4a) pair of thecae. The next pair of thecae possesses small, laterally situated spines. Subsequent thecal orifices lack any genicular processes. The orifices are rather narrow, broadly sub- rectangular or somewhat pyramidal, with markedly thickened apertural lips (Text-fig. 4b). Mature specimens have a dense reticulum of similar thickness to the clathrial framework.

$\mathrm{R}$ e $\mathrm{m}$ a r k s. The present gothograptid form differs from Gothograptus domeyki KozŁowska et al., 2019 in having markedly longer finite rhabdosome, with up to 12 pairs of thecae, more widely spaced thecae and small genicular hoods developed on first, and rarely, second pair of thecae. Other characters, such as the absence of any apertural/genicular processes on most thecae and thickened apertural lips are shared with G. domeyki, which is known to date solely from the upper lundgreni Biozone of Lithuania (Kozłowska et al. 2019). Also specimens described by Bouček and Münch (1952) from the lundgreni Biozone of Bykoš and Borek localities and assigned to Gothograptus nassa (HoLm, 1890) belong to this form. All figured specimens represent mature rhabdosomes, up to $13 \mathrm{~mm}$ long, $1.0-1.2 \mathrm{~mm}$ wide, with up to 12 pairs of thecae. Thecal orifices are narrow, broadly pyramidal, with thickened lips, small lateral spines in some proximal thecae but generally lacking nassa-type hoods. Well-developed appendix and dense reticulum are consistent with full maturity of the colonies.

Abundant occurrence of two early gothograptids of Baltic provenance in the upper lundgreni graptolite Biozone of the Prague Synform is in full compliance with close links between Homerian graptolite faunas of peri-Gondwanan Europe (namely of Perunica microplate) and Baltica.

\section{Genus Semigothograptus KozŁowsKa, 2016}

\section{Semigothograptus meganassa (RICKARds et PALMER, 2002)}

Text-figs $3 \mathrm{c}, 4 \mathrm{~g}$

2001 Gothograptus nassa HoLm (wide form); KozłowskaDawidziuk et al., pp. 151-152, text-fig. 4, figs 8-12.

2002 Gothograptus? meganassa sp. nov.; Rickards and Palmer, pp. 228-231, text-fig. 4.

2016 Semigothograptus meganassa (RickARds et PALMER); Kozłowska, pp. 536-540, figs 1d, 2b, 3, 4b, 7a-d.

2019 Semigothograptus aff. meganassa (RicKards et PALMER); Manda et al., figs $8 \mathrm{~h}, 10 \mathrm{~d}$.

Holotype. Specimen no SX.28550a-b (part and counterpart) from the upper Homerian at Aston Piggot, Long Mountain, Shropshire, UK; figured by Rickards and Palmer (2002: fig. 4a, b).

Material. Single complete flattened rhabdosome from the uppermost lundgreni Biozone of Kosov 2 section (sample K2/6; see Manda et al. 2019: fig. 2) and several poorly preserved fragments from the same level, questionably assigned to this form.

Diagnosis. As for the monospecific genus, see Kozłowska (2016).

Description. Rhabdosome with 9 distinct pairs of thecae is $10.5 \mathrm{~mm}$ long. It widens from $1.36 \mathrm{~mm}$ at the first thecal pair, through $1.87 \mathrm{~mm}$ at the $3^{\text {rd }}$ thecal pair to the maximum width $2.1 \mathrm{~mm}$ attained at the $5^{\text {th }}$ thecal pair. Reticulum is dense proximally, becoming much less developed in the distal part. Proximal end rounded, no details of ancora can be recognized in the present material. Rhabdosome development is non-finite, without appendix. 

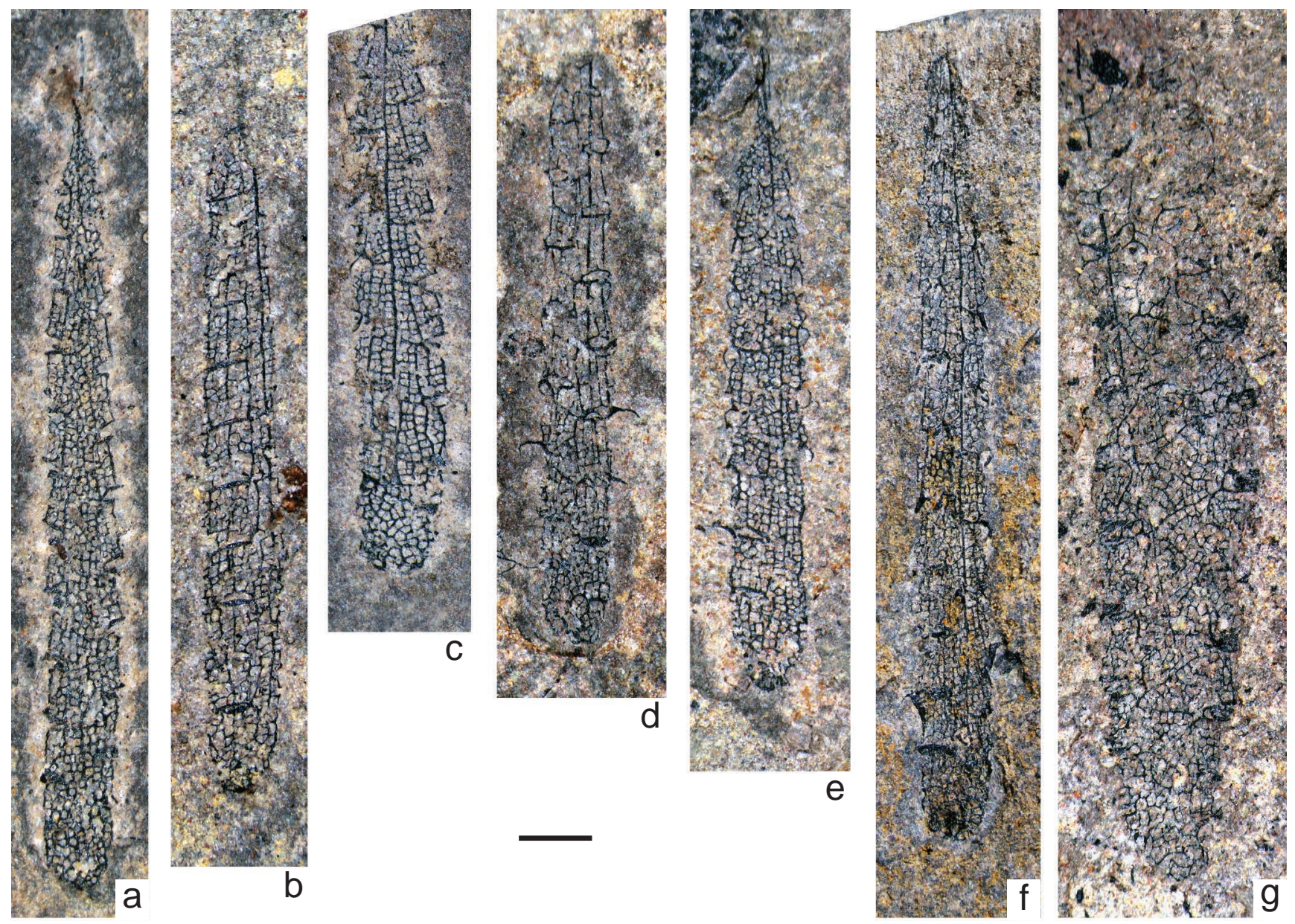

Text-fig. 4. Retiolitid graptolites from the upper lundgreni Biozone of the Kosov section. a-c-Gothograptus aff.domeyki KozkowsKa et al., 2019: a - PŠ 3869, finite rhabdosome in profile with small nassa-type genicular hoods on $1^{\text {st }}$ and $2^{\text {nd }}$ pair of thecae, sample K2/18; b - PŠ 3905, specimen in latero-ventral view showing narrow orifices, thickened thecal lips and very small genicular hood on th 1 , sample K2/22; c - PŠ 3877b, specimen in obverse view with small genicular hoods on th1 ${ }^{1}$ and th $1^{2}$, and small lateral spines in the next two thecae, sample K2/15. d-f - Gothograptus kozlowskii KozŁowSKA-DAWIDZIUK, 1990: d - PŠ 3878, specimen showing broadened bases of the apertural spines, sample K2/11; e - PŠ 3870, finite rhabdosome in obverse profile view, sample K2/13; f - PŠ 3868, latero-ventral (subscalariform) view, sample K2/21. g - Semigothograptus meganassa (RICKARDS et PALMER, 2002): PŠ 3863 , sample K2/6. All specimens $\times 10$, scale bar $1 \mathrm{~mm}$.

The free, continuous nema runs inside the rhabdosome, and further distally out of the thecate part. Genicular hoods are only slightly developed in the two most proximal pairs of thecae. Subsequent thecal apertures are furnished with solid, nassa-type genicular hoods. Rather long lateral apertural rods, convex to the centre of the lateral wall are seen on the right distal thecae of the present specimen (Text-figs 3c, $4 \mathrm{~g}$ ), which also exhibits prominent oblique lateral lists of the ancora sleeve. 2TRD increases from $1.5 \mathrm{~mm}$ at th2 to $1.9 \mathrm{~mm}$ at th5.

Remarks. This form can be readily distinguished from its presumed gothograptid ancestors by its unfinished rhabdosome (lacking an appendix) with free nema, and maximum width of about $2.1 \mathrm{~mm}$, which is attained as late as at the $5^{\text {th }}$ thecal pair. It resembles Gothograptus nassa (HoLm, 1890 ) in having solid, rather prominent apertural hoods, but markedly differs in having a non-finite rhabdosome widening from $1.3-1.4 \mathrm{~mm}$ to the maximum $2.1 \mathrm{~mm}$ attained at about the fifth thecal pair. The present material from the Kosov 2 section moves the FAD of $S$. meganassa from the parvusnassa Biozone down to the uppermost lundgreni Biozone.
The present FAD of $S$. meganassa predates the so far known FAD of the widely recorded and very common $G$. nassa, and therefore calls into question its derivation from $G$. nassa as presumed by Kozłowska (2016).

Semigothograptus meganassa is known from Avalonia (England, Rickards and Palmer 2002), Baltica (Poland, Kozłowska 2016) and peri-Gondwanan Europe (Germany, Thuringia, G. meganassa, sensu Jaeger (1991); the Czech Republic, G. nassa wide form, sensu Kozłowska et al. (2001)). In the Czech Republic, this form occurs in Všeradice (Kozłowska et al. 2001), Nesvačily (PŠ, unpublished personal observation) and Kosov (this paper) sections. Semigothograptus meganassa has been reported from the post-extinction parvus, nassa and praedeubeli-deubeli biozones (Kozłowska 2016), but the present occurrence in the pre-extinction uppermost lundgreni Biozone qualifies S. meganassa for second retiolitine survivor of the middle Homerian lundgreni mass extinction event. Palaeogeographic distribution of $S$. meganassa coincided with that of $G$. nassa and other species of the genus Gothograptus (see Kozłowska 2016, Kozłowska et al. 2019). 


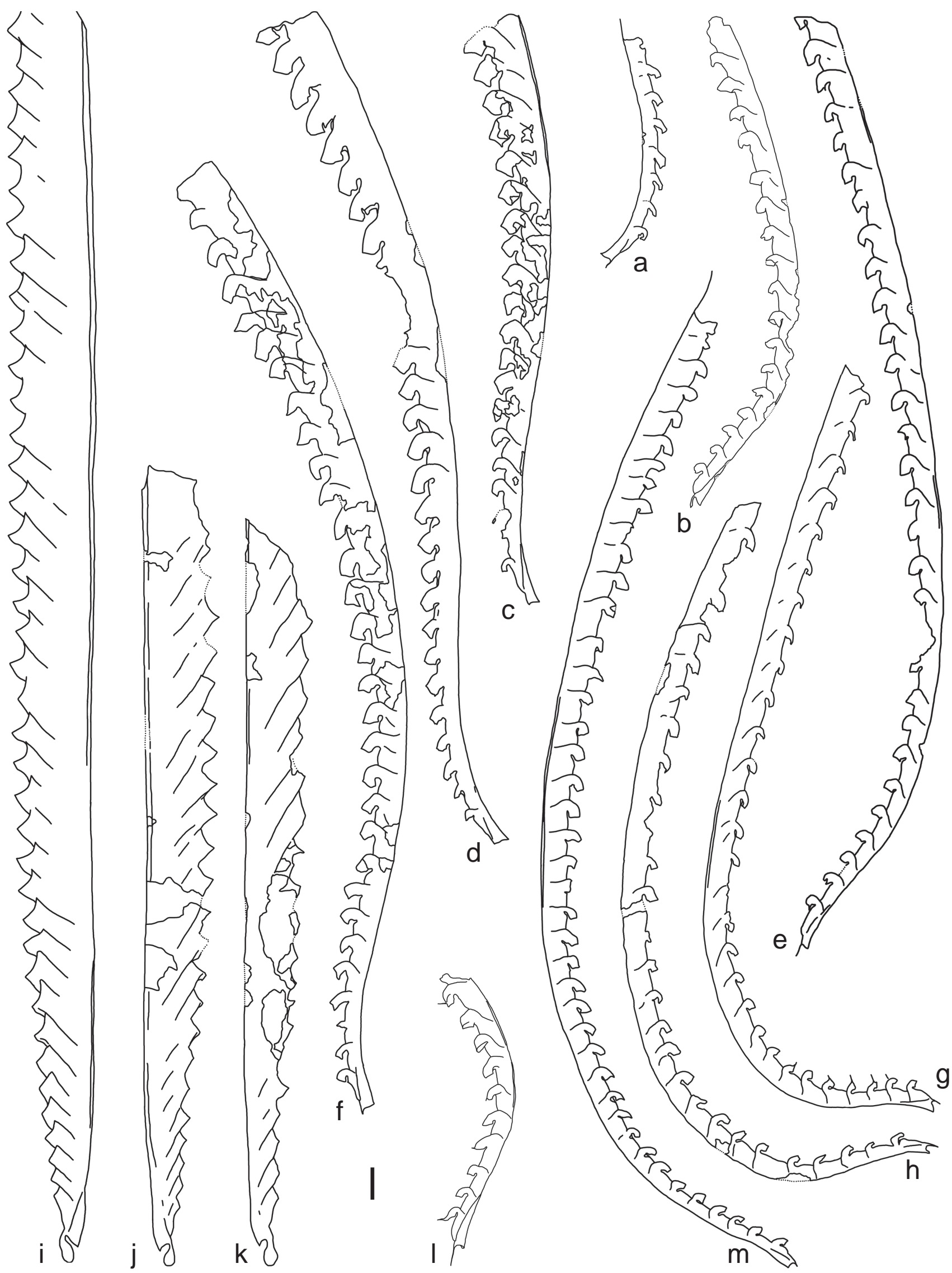

Text-fig. 5. Monograptid graptolites from the upper lundgreni (a-h, l-m) and lower ludensis-gerhardi (i-k) biozones of the Kosov quarry. ?a, c-d, f-Monograptus subflexilis P̌̌IBYL, 1941: a - PŠ 3874, slender juvenile specimen from sample K2/11; c - PŠ 3871/1, sample K2/13; d - PŠ 3871/2, sample K2/13; f - PŠ 3864, sample K2/12. b, e, g-h, l-m - Monograptus ambiguus JAEGER, 1991: b PŠ 3899, sample K2/7; e - PŠ 3896, least ventrally curved specimen, sample K2/7; g - PŠ 3873, specimen showing small apertural spines in proximal thecae, sample K2/6; h - PŠ 3851, most ventrally curved specimen from sample K2/6; I - PŠ 3883, sample K2/6; m - PŠ 3866, sample K2/7. i-k - Pristiograptus auctus RICKARDS, 1965: i - PŠ 3848/2, sample K1/32; j - PŠ 3848/1, sample K1/32; k - PŠ 3839, sample K1/32. All specimens $\times 6$, scale bar 1 mm. 
Genus Pristiograptus JAEKEL, 1889

\section{Pristiograptus auctus RICKARDS, 1965}

Text-figs 5i-k, 6a, 7c

1965 Pristiograptus auctus sp. nov.; Rickards, pp. 260-261, text-fig. 2h, pl. 31, figs 2-4.

1970 Pristiograptus auctus Rickards; Palmer, pp. 340-341, pl. 14, figs h-p, pl. 15, figs c-d.

1975 Pristiograptus auctus RicKARDs; Lenz, pp. 84, 86, text-fig. 3a-d, pl. 1, figs 1-2.

1991 Monograptus auctus?; Jaeger, fig. 1.

1993 Pristiograptus auctus RicKARDS; Burns and Rickards, fig. 4b.

1998 Pristiograptus auctus RicKARDs; Maletz et al., p. 145, textfig. 4/7, pl. 1, fig. 7 .

2019 Pristiograptus auctus RicKARDs; Manda et al., figs 7a, 9d, e.

H o l o ty p e. Specimen no HUR/7W/46 from the lower nilssoni Biozone (lowermost Ludlow) of Wandale Hill, Howgill Fells, England; figured by Rickards (1965: text-fig. 2h, pl. 31, fig. 4).

Material. 8 flattened, mostly complete specimens from the lower - middle ludensis-gerhardi Biozone of the Kosov 1 section (samples K1/31 and K1/32; see Manda et al. 2019: fig. 3).

Diagnosis. After Rickards (1965), emended. Robust pristiograptid rhabdosome with slightly ventrally curved dorsal wall in the proximal part comprising th1th5. The sicula is gently ventrally curved, in particular near its concave, ventro-proximally facing aperture, and is commonly furnished with a weakly developed rutellum. The sicular aperture is somewhat covered by a short and robust virgella, which is expanded into a prominent globular structure.

Description. The robust, almost $50 \mathrm{~mm}$ long, generally straight rhabdosome is weakly ventrally curved in the proximal part comprising th1-th5. The sicula is 1.85$2.0 \mathrm{~mm}$ long, markedly ventrally curved near the aperture, which is slightly concave and faces ventro-proximally, being furnished with a broad, weakly developed rutellum. The sicular aperture is somewhat covered by a short (0.7-0.8 $\mathrm{mm}$ ) and blunt virgella, which is expanded into a prominent, presumably spatulate or almost globular structure. Ventral wall of th1 is slightly concave, and emerges $0.34-0.42$ $\mathrm{mm}$ above the sicular apertural margin. Thecae are straight simple tubes with slightly concave apertures, which are either perpendicular to the thecal tube or somewhat everted. Proximal thecae overlap for less than two-thirds of their length, distal thecae overlap for two-thirds or a little more and are inclined at an angle of $34-55^{\circ}\left(\mathrm{M}=44^{\circ}, \mathrm{n}=12\right)$ to the rhabdosome axis. The rhabdosome widens from 0.85 $1.02 \mathrm{~mm}$ at th1 to $0.94-1.2 \mathrm{~mm}$ at th3, 1.28-1.65 $\mathrm{mm}$ at th5, $1.65-2.2 \mathrm{~mm}$ at th10 and $2.1-2.55 \mathrm{~mm}$ at th20 to the distal maximum $2.8 \mathrm{~mm}$. Most proximal thecae are rather densely spaced with 2TRD $1.34-1.6 \mathrm{~mm}$ at th2 and $1.53-1.87 \mathrm{~mm}$ at th5. Thereafter the 2TRD increased to $2.0-2.1 \mathrm{~mm}$ at th10, and the most distal thecae number 9 in $10 \mathrm{~mm}$ with 2TRD $2.2 \mathrm{~mm}$.

Remarks. Specimens from the lower part of the ludensis-gerhardi Biozone of the Kosov 1 section appear like somewhat enlarged versions of the holotype and paratypes of $P$. auctus from the Neodiversograptus nilssoni Biozone of northern England, which are $0.7-0.75 \mathrm{~mm}$ wide at th1 and $2.0 \mathrm{~mm}$ wide distally, with thecae numbering 11-18 in 10 mm (Rickards 1965). Palmer (1970) described "Monograptus" auctus from the ludensis Biozone of Ireland with thecal spacing $10-12$ in $10 \mathrm{~mm}$ proximally and 8-10 in $10 \mathrm{~mm}$ distally, which matches our specimens from Kosov 1. Rickards (1965) noted the close similarity of $P$. auctus to Colonograptus ludensis (MuRCHISON, 1839) and Pristiograptus tumescens (Wood, 1900), in having similar thecal spacing and dorso-ventral width, along with a slightly ventrally curved dorsal side of the proximal part of the rhabdosome. The sicula is markedly ventrally curved near the aperture, which is well seen on Palmer's illustrations (1970: pl. 14), along with the globular virgellar structure which "almost blocks the sicular aperture". The weak ventral curvature of the dorsal wall of the proximal part of the rhabdosome, ventrally curved sicula, its ventro-proximally facing aperture and bulbous virgella are considered the most diagnostic characters of the species, considering variation in thecal spacing and rhabdosome width that is common in Wenlock and Ludlow pristiograptids and derived colonograptids. The stratigraphic range of $P$. auctus is restricted to the uppermost Homerian ludensis-gerhardi and lowermost Gorstian nilssoni biozones, according to records from Wales, England, Ireland, Québec (Canada), Thuringia (Germany), Albania and the Czech Republic.

\section{Genus Monograptus Geinitz, 1852}

Monograptus ambiguus JAEGER, 1991

Text-figs 5b, e, g-h, l-m, 6c, e, 7b, d-e

1965 Monograptus subflexilis PřııYL; Jaworowski, text-fig. 3, fig. 6 , pl. 1, fig. 6 .

1991 Monograptus ambiguus sp. n.; Jaeger, pp. 343, 345, 347, figs 1, 29/8, 10 .

2019 Monograptus ambiguus JAEGER; Manda et al., figs 7a, 9d, e.

Holotype. Specimen no MBg705.1 from the uppermost lundgreni Biozone of the Gräfenwarth section, Thuringia, Germany; figured by Jaeger (1991: fig. 29/8, 10).

M a t e ri a l. 59 mostly complete flattened rhabdosomes from the uppermost lundgreni Biozone of the Kosov 2 section (samples K2/8-K2/5; see Manda et al. 2019: fig. 2)

Di a gno sis. After Jaeger (1991), emended. Rhabdosome ventrally curved with slight dorsal curvature at the proximal end comprising th1-th2. Sicula straight or slightly dorsally curved. Thecae hooked, overlapping for about one-quarter their length, with steeply inclined interthecal septa, curved prothecae and ventral prothecal walls parallel to the rhabdosome axis. Dorso-ventral width increases gradually from about $0.7 \mathrm{~mm}$ at th 1 to the maximum $1.3 \mathrm{~mm}$ most distally. Metathecal hooks comprise half the rhabdosome's width in proximal thecae and onethird the width in distal thecae.

Description. Rhabdosome is very gently dorsally curved over th1-2. Thereafter, it is moderately ventrally curved, until at least th14-33. Ventral curvature varies among specimens, but becomes almost negligible distally, which is well seen in more than $30 \mathrm{~mm}$ long, mature rhabdosomes. 

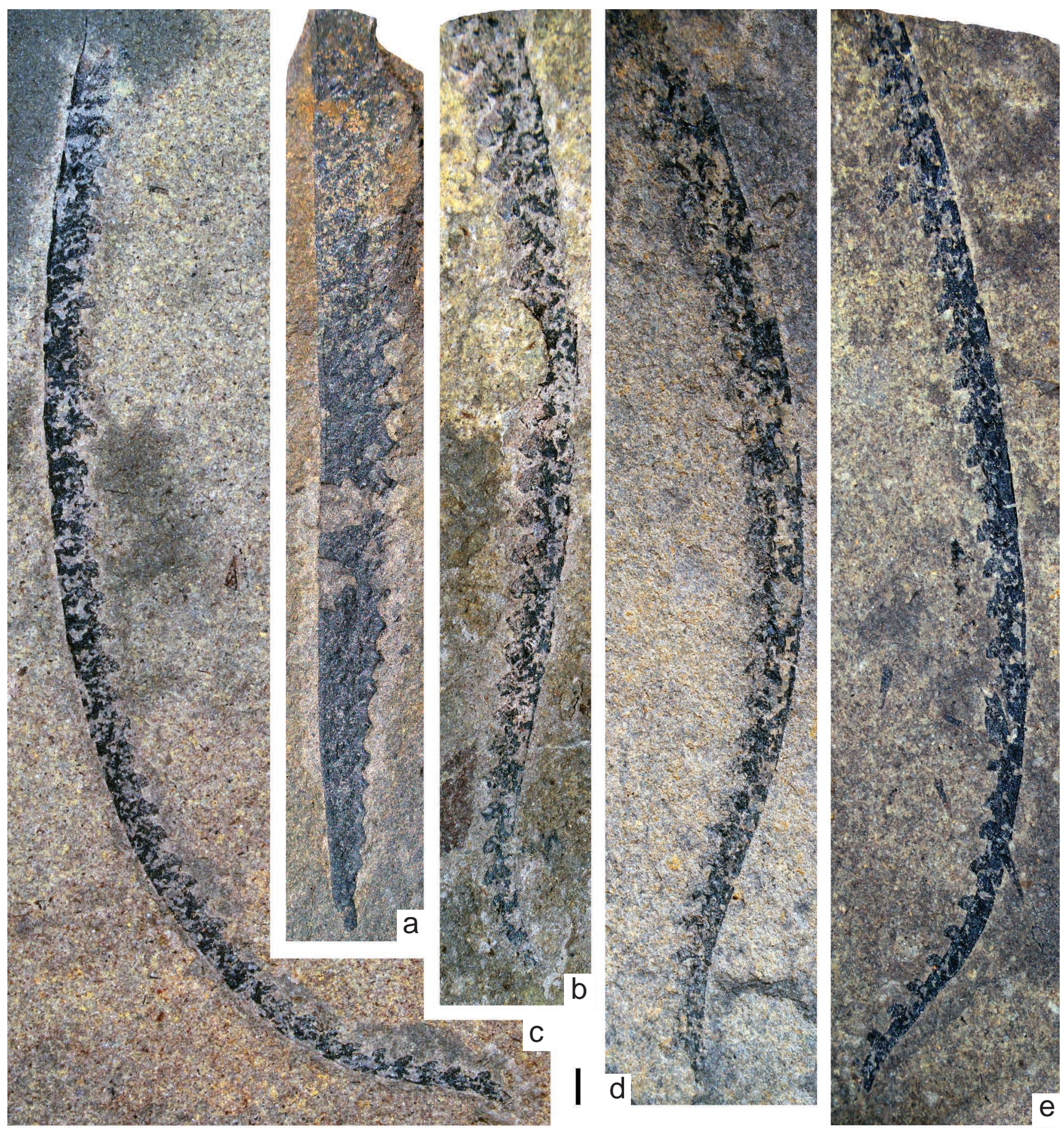

Text-fig. 6. Monograptid graptolites from the upper lundgreni (b-e) and lower ludensis-gerhardi (a) biozones of the Kosov quarry. a - Pristiograptus auctus RICKARds, 1965: PŠ 3848/1, sample K1/32. b, d - Monograptus subflexilis PřIBYL, 1941: b - PŠ 3871/2, sample K2/13; d - PŠ 3864, sample K2/12. c, e - Monograptus ambiguus JAEGER, 1991: c - PŠ 3866, sample K2/7; e - PŠ 3896, sample K2/7. All specimens $\times 6$, scale bar $1 \mathrm{~mm}$.

The sicula is $1.5-1.85 \mathrm{~mm}$ long and $0.22-0.33 \mathrm{~mm}$ wide across its concave aperture, which is furnished with a tiny virgella. Sicular apex attains the middle or the dorsal wall of th2. Protheca of th1 begins with a prominent bulge $0.17-0.2$ $\mathrm{mm}$ from the sicular aperture (e.g. see Text-fig. 5b, e, 1). It is strongly curved in a similar manner to all other prothecae, which have ventral walls either parallel to the rhabdosome axis or very gently $\left(\leq 2^{\circ}\right)$ inclined. Thecae overlap for about one-quarter their length; interthecal septa are steeply inclined at an angle of $50-85^{\circ}$. Metathecae are hooked, with proximally facing apertures, in proximal thecae probably furnished by short, paired lateral spines. Metathecal hook comprises from one-half the rhabdosome's dorso-ventral width in proximal thecae to one-third in distal thecae. Dorso-ventral width of the rhabdosome increases gradually from $0.64-0.84 \mathrm{~mm}$ at th1 $(\mathrm{M}=0.72, \mathrm{n}=10)$ to $0.72-0.84$ at th3 $(\mathrm{M}=0.76 \mathrm{~mm}, \mathrm{n}=10), 0.77-0.93 \mathrm{~mm}$ at th5 $(\mathrm{M}=0.85$, $\mathrm{n}=10)$, and $0.92-1.2 \mathrm{~mm}$ at th10 $(\mathrm{M}=0.99, \mathrm{n}=9)$ to the maximum $1.27 \mathrm{~mm}$ attained by th 40 . 2TRD increases from $1.28-1.73 \mathrm{~mm}$ at th2 $(\mathrm{M}=1.6 \mathrm{~mm}, \mathrm{n}=10)$ to $1.45-1.95 \mathrm{~mm}$ at th10 $(\mathrm{M}=1.71, \mathrm{n}=10)$. Distal thecae number 10 in 10 $\mathrm{mm}$, with 2TRD ranging from 1.8 to $2.1 \mathrm{~mm}$. 
R e m a rks. Rich material of Monograptus ambiguus found in the uppermost lundgreni Biozone of the Kosov 2 section (Manda et al. 2019) matches the limited type material of the species described by Jaeger (1991) from the uppermost Testograptus testis Subzone (uppermost lundgreni Biozone) of the Gräfenwarth section, Thuringia in rhabdosome form, thecal form and measured parameters. The present material from the Kosov quarry, however, revealed remarkable variability in the ventral curvature of the rhabdosome, and has shown that specimens from the uppermost lundgreni Biozone of Bartoszyce and Gołdap boreholes in NE Poland, refered to Monograptus subflexilis PřıBYL, 1941 by Jaworowski (1965), also belong to M. ambiguus. Thus, the species, so far recorded in Germany, the Czech Republic and Poland, qualifies as a useful biostratigraphic marker of the uppermost part of the lundgreni Biozone in Europe. Monograptus ambiguus can be readily distinguished from M. subflexilis by its very short, gently dorsally curved proximal portion of the rhabdosome, more prominent subsequent ventral curvature, much narrower and more slowly increasing dorso-ventral width, relatively longer ventral prothecal walls, almost parallel to the stipe, and much smaller apertural hooks. Maximum width of the rhabdosome does not exceed $1.3 \mathrm{~mm}$ in $M$. ambiguus, in contrast to about $3 \mathrm{~mm}$ in M. subflexilis. The simply hooked thecal form of $M$. ambiguus is closely similar to that of M. subflexilis, which indicates that, despite superficial similarity to Homerian species with S-shaped or ventrally curved rhabdosomes and coiled, streptograptid-like thecae (Monograptus retroflexus TullBerg, 1883 and Monograptus serexiguus JAEGER, 1991), M. ambiguus is a true, although more derived offshoot from the priodon-flemingii monograptid stem line.

\section{Monograptus subflexilis Pर̌ıBYL, 1941}

$$
\text { Text-figs 5c-d, f, ?a; 6b, d }
$$

1941 Monograptus subflexilis n. sp.; Přibyl, pp. 3-4, pl. 1, figs 2-4, ?1.

1943 Monograptus subflexilis Přı̀Y; Přibyl, p. 10, pl. 1, figs 4-5.

? 1990 Monograptus sp. aff. M. flexilis ElLes; Lenz and Melchin, fig. 3J-L.

? 1991 Monograptus aff. flexilis ElLEs; Lenz and Melchin, pp. 229-230, fig. $17 \mathrm{f}-\mathrm{h}$.

2019 Monograptus subflexilis PřıBYL; Manda et al., fig. 8h, i.

H o l o t y p e. Specimen no NM-L 30948 from the testis (upper lundgreni) Biozone exposed in a small quarry south of Bykoš, figured by Přibyl (1941: pl. 1, fig. 3).

Material. 15 complete flattened rhabdosomes and 14 incomplete rhabdosomes and fragments from the upper lundgreni Biozone of the Kosov 2 section (samples K2/15K2/11; see Manda et al. 2019: fig. 2) and material figured by Přibyl (1941, 1943).

Diagnosis. Rhabdosome doubly curved, with proximal part comprising 4-6 thecae dorsally curved, thereafter ventrally curved with curvature decreasing distally. Sicula very slightly dorsally curved, with tiny virgella. Hooked thecae of priodon-type, with relatively broad ventroproximally facing aperture and only slightly inclined ventral prothecal wall. Dorso-ventral width increases steadily from $0.7 \mathrm{~mm}$ at th1 to $1.6-1.95 \mathrm{~mm}$ at th20, thereafter slowly increases to $2.9-3.0 \mathrm{~mm}$ at th50-60. Distal thecae number 10 in $10 \mathrm{~mm}$, proximal thecae more tightly spaced.

D e s c ription. The rhabdosome is characteristically doubly curved, in excess of $100 \mathrm{~mm}$ long. The proximal part, comprising the first $4-6$ thecae is slightly but distinctly dorsally curved. Thereafter, curvature gradually switches to ventral, which decreases distally, so that the distal part becomes straight from th20-30. The sicula is very gently dorsally curved, 1.6-1.7 $\mathrm{mm}$ long and $0.34-0.45 \mathrm{~mm}$ wide across the aperture. The apex attains the level of the dorsal wall of th2. First theca originated $0.2-0.25 \mathrm{~mm}$ from the sicular aperture. The thecae are hooked, with metathecal hook comprising about two-fifths the rhabdosome's dorso-ventral width. Thecal apertures are directed ventroproximally; thecal overlap is one-quarter to one-third in proximal thecae and slightly exceeds one-half in distal thecae. Ventral prothecal wall is only slightly inclined to the rhabdosome axis, as opposed to the steeply inclined interthecal septum. Dorso-ventral width of the rhabdosome increases steadily from $0.7-0.8 \mathrm{~mm}$ at th1, to $0.8-0.85 \mathrm{~mm}$ at th3, $0.9-1.1 \mathrm{~mm}$ at th5, $1.3-1.4 \mathrm{~mm}$ at th10 and $1.6-1.95$ $\mathrm{mm}$ at th20. Thereafter the rate of increase in dorso-ventral width slows down, until a width of $2.9 \mathrm{~mm}$ is attained at about th50. Distal fragments questionably assigned to $M$. subflexilis are ca. $3.0 \mathrm{~mm}$ wide. 2TRD is $1.53-1.7 \mathrm{~mm}$ at th2 and $1.7-0.8 \mathrm{~mm}$ at th10. Distal thecae number 10 in $10 \mathrm{~mm}$, with 2TRD ranging from 1.85 to $2.1 \mathrm{~mm}$.

Remarks. Monograptus subflexilis is known solely from the lundgreni Biozone of the Prague Synform, the Czech Republic. The species was most likely derived from the priodon-flemingii stem line, from which it is primarily distinguished by having a more or less moderately sigmoidal rhabdosome. Teller (1986: 55) lumped M. subflexilis in Monograptus flemingii (SALTER, 1852). The present material of $M$. subflexilis suggests that this assessment was not correct.

Monograptus subflexilis can be consistently distinguished from the Sheinwoodian and Homerian M. flemingii in that the latter has a markedly higher rate of rhabdosome widening in the proximal and mesial parts of the rhabdosome, a longer sicula, and proximal dorsal curvature of the generally straight rhabdosome commonly limited to the 2-4 most proximal thecae. Distal fragments of $M$. flemingii are still wider than those of $M$. subflexilis, and apertural hooks are more curved so that thecal apertures face proximally rather than proximo-ventrally.

The middle-upper Sheinwoodian Monograptus belophorus (MENEGHINI, 1857), although rather variable in general shape of the rhabdosome, is markedly less robust and generally more dorsally curved in the proximal part. It has a longer sicula, a characteristically long and robust virgella, and less developed apertural hooks. Monograptus belophorus itself is a senior synonym of $M$. flexilis. Lenz and Melchin (1990, 1991) illustrated and briefly described the smoothly sigmoidal Monograptus aff. flexilis ELLEs, 1900 from the middle - upper Sheinwoodian of the Canadian Arctic islands, and Obut and Sennikov (1977) reported similar specimens assigned to $M$. flexilis flexilis in association with Cyrtograptus tchukotkaensis OBuT et SenNikov, 1977 (= Cyrtograptus multiramis TöRnQuist, 1910) from the Chukotka Peninsula, Russia. Despite their stratigraphically 

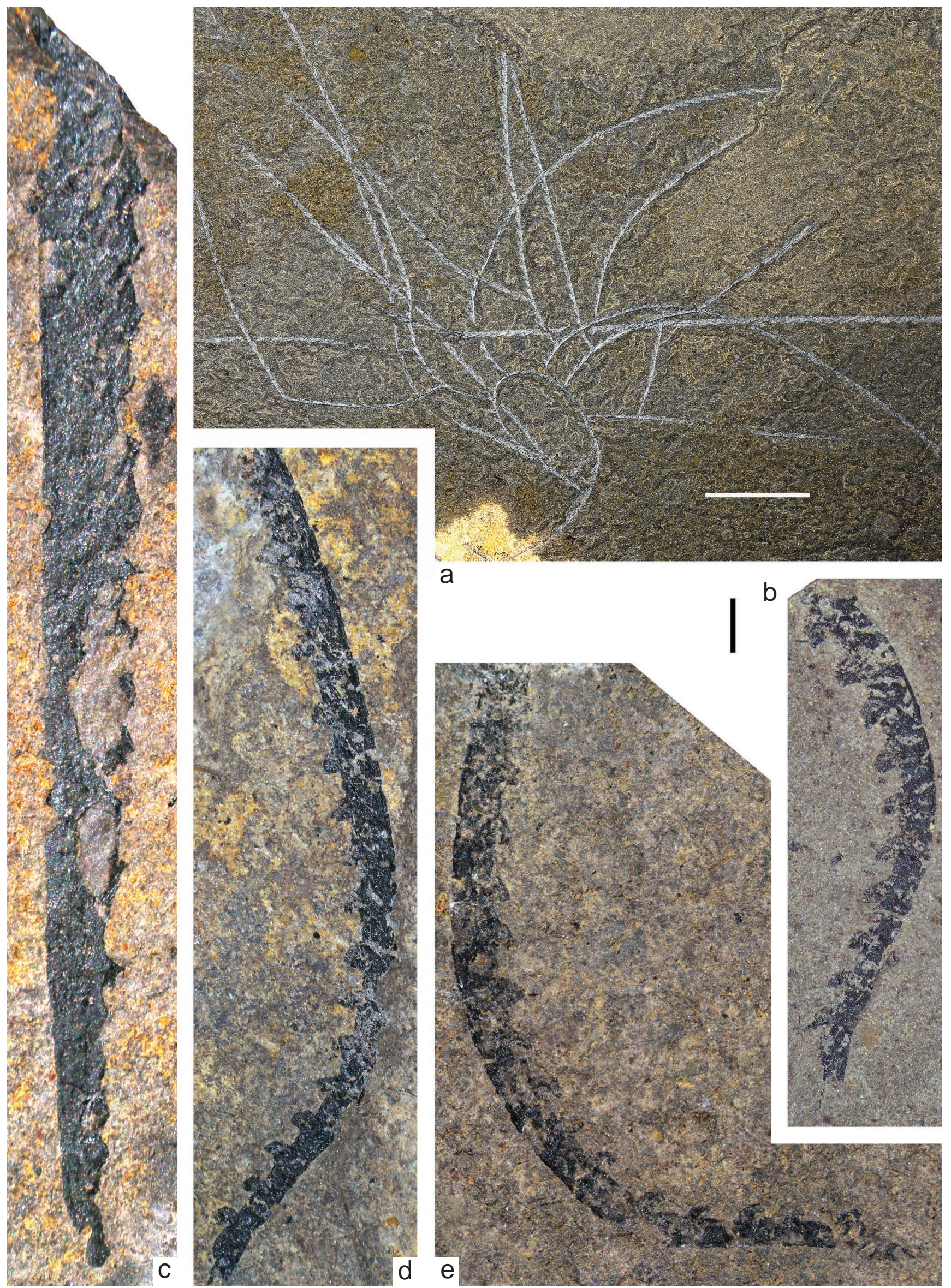

Text-fig. 7. Monograptid graptolites from the upper lundgreni (a-b, d-e) and lower ludensis-gerhardi (c) biozones of the Kosov quarry. a - Cyrtograptus hemmanni BoUČEK, 1934: PŠ 3902a, sample K2/10. b, d-e - Monograptus ambiguus JAEGER, 1991: b - PŠ 3883, sample K2/6; d - PŠ 3899, sample K2/7; e - PŠ 3851, ventrally curved proximal part of the specimen figured on Text-fig. 5h, sample K2/6. c - Pristiograptus auctus RICKARDS, 1965: PŠ 3839, sample K1/32. All specimens $\times 10$, except for (a) $\times 2$. Black scale bar $1 \mathrm{~mm}$, white scale bar $10 \mathrm{~mm}$. 
earlier occurrence, the Canadian specimens match $M$. subflexilis in all parameters, including thecal spacing, used for their differentiation by Lenz and Melchin (1991). The only difference is that the dorsally curved proximal part of M. aff. flexilis, sensu Lenz and Melchin (1991) encompasses a greater number of proximal thecae (12-15 compared to 4-6 in M. subflexilis). The Canadian form is tentatively assigned to $M$. subflexilis in this study.

The early Telychian Stimulograptus utilis Loydell, 1991 exhibits rhabdosome curvature closely similar to that of M. subflexilis, but can be readily distinguished by having considerably lesser DVW, negligible thecal overlap and prominent apertural spines.

\section{Genus Cyrtograptus CARruthers, 1867 \\ Cyrtograptus hemmanni BoUČEK, 1934}

Text-figs 7a, 8a-b

1934 Cyrtograptus hemmanni n. sp.; Bouček, pp. 91-92, pl. 1, figs 3-4.

1952 Cyrtograptus hemmanni BoUčEK; Münch, p. 138, pl. 52, fig. $3 \mathrm{a}-\mathrm{b}$.

2019 Cyrtograptus hemmanni BoučEK; Manda et al., fig. 11.

$\mathrm{H}$ o l o t y p e. Specimen from the testis (upper lundgreni) Biozone of Lerchenhügel near Ronneburg in Thuringia, designated and figured by Bouček (1934: pl. 1, fig. 4), reportedly housed in the Naturkundemuseum Altenburg.

Material. Two flattened specimens from the upper lundgreni Biozone of Kosov 2 section (samples K2/9 and K2/10; see Manda et al. 2019: fig. 2).

D i a g n o s is. Loosely coiled main stipe and several strongly dorsally curved cladia of the first and second order, commonly separated by $2-4$ thecae. Sicula $0.7 \mathrm{~mm}$ long, apex attains dorsal wall of th1. Proximal thecae hooked, high-triangular with small apertural spines, not overlapping. Apertural hooks retained in proximal thecae of primary cladia. Distal thecae are simple, slightly overlapping tubes with dorsally facing apertures. Maximum dorso-ventral width $0.75 \mathrm{~mm}$, attained in pre-cladial part; distal width of main stipe and cladia $0.5-0.6 \mathrm{~mm}$.

Description. A mature, relatively complex rhabdosome from the Kosov quarry possesses a main stipe, which forms a loose helical spiral, with little more than one volution preserved. Diameter of the first whorl is $14 \mathrm{~mm}$, measured between th1 and half of the first whorl. Main stipe bears several (7 in the present specimen) dorsally curved primary cladia, each possessing 1-3 second-order cladia. First primary cladium arises from th 10 , subsequent cladia of the first order are separated by 1-3 (usually 2) thecae. First cladia of the second order arise from the fourth (occasionally third) theca of the primary cladia. Subsequent second-order cladia are separated by further 3-4 thecae. Sicula is small, $0.7 \mathrm{~mm}$ long and $0.28 \mathrm{~mm}$ wide across the aperture. Sicula apex reaches a level immediately below the dorsal wall of th1. Theca 1 and th2 are relatively short and high-triangular, with a hooked apertural part; subsequent proximal thecae are somewhat axially elongated, with a rather narrow prothecal part and triangular metatheca, terminated by a small apertural hook with short, presumably paired lateral spines. Dorso-ventral width increases from $0.62 \mathrm{~mm}$ at thl to the maximum $0.75 \mathrm{~mm}$ attained by th6-7. Proximal thecae are on the convex side of the stipe, until about th16, which gave origin to the third cladium of the first order. Thereafter the main stipe exhibits axial torsion through 180 degrees within subsequent 8-9 thecae, so that the more distal thecae occur on the concave, "inner-facing" side of the stipe. Thecal apertural hook apparently retreats beginning at about th1315. Distal thecae, growing on convex part of the procladium are low and triangular, with rather distally facing apertures, and DVW ca. $0.55 \mathrm{~mm}$. Primary cladia commence with triangular, partly isolated thecae having slightly curved, somewhat hooked apertural parts, and apertures still furnished with tiny spines. Subsequent thecae become lowtriangular in outline, with dorsally facing apertures similar to those of the distal part of the main stipe. No overlap has been observed between the thecae. Dorso-ventral width of the cladia is $0.5-0.55 \mathrm{~mm}$. 2TRD is $1.7 \mathrm{~mm}$ at th2, $1.92 \mathrm{~mm}$ at th5 and $1.87 \mathrm{~mm}$ at th10. Distal thecae of both the main stipe and cladia number 8.5 in $10 \mathrm{~mm}(2 \mathrm{TRD}$ dist. $=2.34$ $2.38 \mathrm{~mm}$ ). A second, incomplete and somewhat deformed rhabdosome matches well the specimen described above in all principal features and measured parameters.

R e marks. Bouček (1934) described C. hemmanni based on two specimens from the Thuringian Testograptus testis Biozone, which probably corresponds with the upper lundgreni Biozone of the Kosov 2 section, considering the known stratigraphic range of Testograptus testis (BARRANDE, 1850) in central Europe. The primary stipe of the type specimen is loosely coiled for about 360 degrees. Cladia of the first and second order are separated by 3-5 thecae, as opposed to 1-4 thecae in the present specimens from Kosov 2. However, distinct variation in the spacing of cladia can be observed even within each of the two specimens from Kosov. Dorso-ventral width is $0.5-0.6 \mathrm{~mm}$ in the Thuringian holotype, which is consistent with the distal width of 0.55 $\mathrm{mm}$ recorded in the Kosov material. The latter, however, attains a maximum DVW of $0.75 \mathrm{~mm}$ in its proximal, hooked triangular thecae. Both Bohemian and Thuringian specimens retain hooked thecae until the level of axial torsion of the main stipe, which begins after the third or fourth cladium. Hooked thecae with minute spines are also developed in the proximal parts of primary cladia. More detailed comparison is barely possible, due to the poor preservation and missing proximal end in the Thuringian specimens.

Cyrtograptus hemmanni has been recorded to date only from the upper lundgreni Biozone of Thuringia, Germany (Bouček 1934, Münch 1952, Jaeger 1991), and central Bohemia, the Czech Republic (Manda et al. 2019). The species, which exhibits hooked, relatively high triangular most proximal thecae and slender stipes, resembling those of Cyrtograptus hamatus (BAILY, 1861) can be readily differentiated from the latter by its loosely coiled rhabdosome, much less abrupt axial twisting of the main stipe, and numerous cladia of first and second order. Cyrtograptus lundgreni TulbBerg, 1883 has a markedly larger and more robust rhabdosome, widely spaced primary cladia, and strongly axially elongated, low triangular metathecae, which become high triangular and considerably isolated before the start of axial twisting of the stipe. Cyrtograptus ramosus 


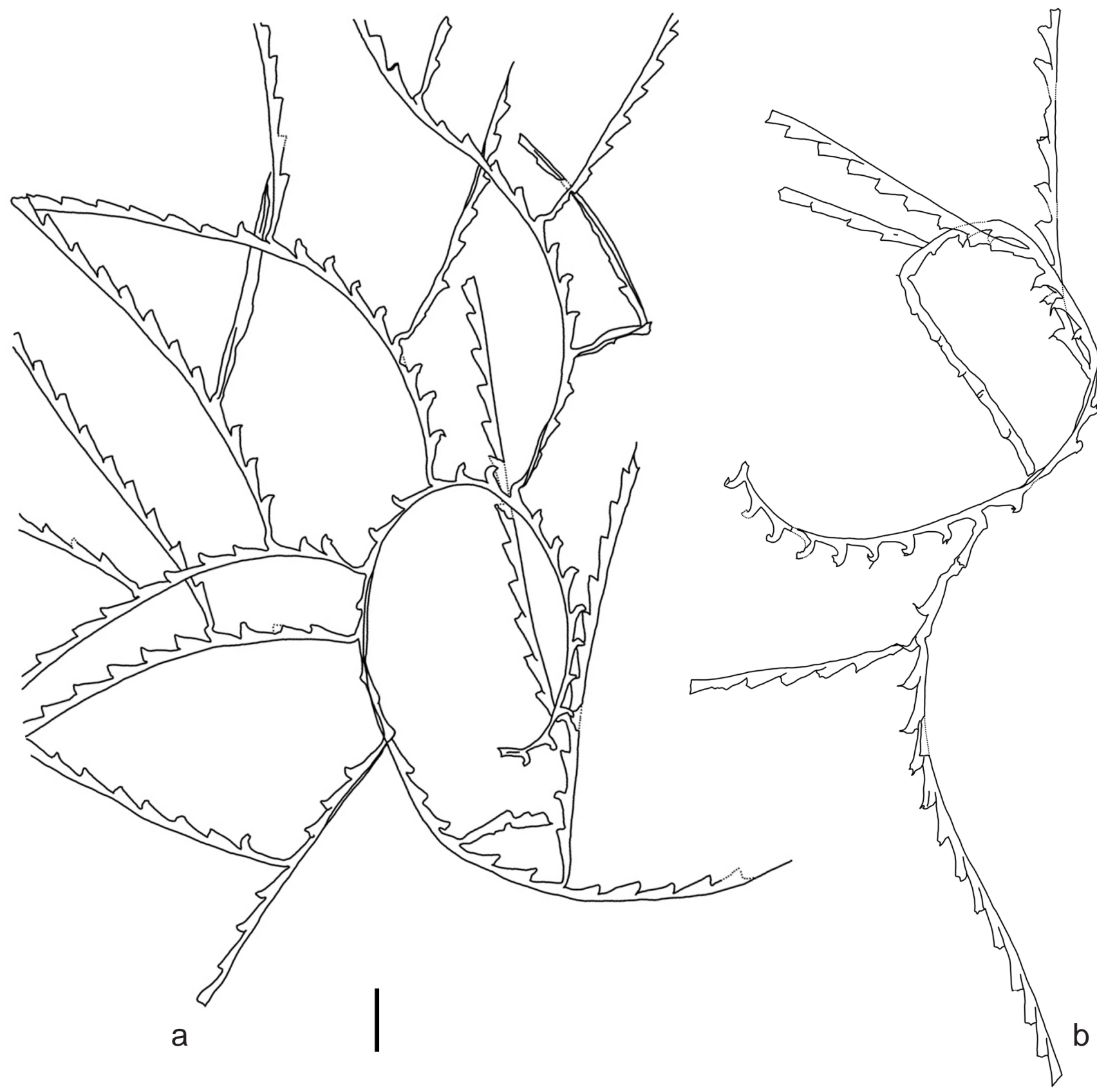

Text-fig. 8. Cyrtograptus hemmanni BoučEK, 1934 from the upper lundgreni Biozone of the Kosov 2 section. a - PŠ $3902 \mathrm{~b}$, central part of large rhabdosome, for complete counterpart see Text-fig. 7a, sample K2/10; b - PŠ 3886/2, deformed rhabdosome from sample K2/9. Both specimens $\times 5$, scale bar $2 \mathrm{~mm}$.

BouČEK, 1931a possesses axially elongated proximal thecae, along with straight cladia of the first order. Secondary cladia have not been recorded. Cyrtograptus mancki BoučEK, 1931b has a tightly coiled proximal part and densely spaced, generally straight cladia separated by a single theca. Cyrtograptus multiramis differs in having a markedly robust rhabdosome, and somewhat straightened proximal part of the main stipe with low-triangular, axially elongated thecae.

\section{Acknowledgements}

The financial support provided by the Czech Science Foundation through project 14-16124S is acknowledged. P.S. appreciated further support received from the Institute of Geology of the Czech Academy of Sciences (RVO
67985831). Š.M. acknowledges support provided by the Czech Geological Survey (339900). Special thanks are due to reviewers Anna Kozłowska and David Loydell for their valuable comments on the earlier version of the manuscript.

\section{References}

Barrande, J. (1850): Graptolites de Bohême. - Chez l'auteur, Prague, 74 pp.

Baily, W. H. (1861): Graptolites from Co. Meath. - Journal of the Geological Society of Dublin, 9: 300-306.

Bouček, B. (1931a): Sur la presence de la zone à Cyrtograptus rigidus TullB. et d'autres zones dans le Gothlandien de la Bohême. - Věstník Státního geologického ústavu Československé republiky, 7: 85-98. 
Bouček, B. (1931b): Communication préliminaire sur quelques nouvelles espèces de Graptolites provenant du Gothlandien de la Bohême. - Věstník Státního geologického ústavu Československé republiky, 7: 293-313.

Bouček, B. (1934): Über ein neues interessantes Fossil (Hallotheca n.g.) und eine neue Cyrtograptenart (Cyrt. hemmanni n. sp.) aus dem thüringischen Silur. - Beiträge zur Geologie von Thüringen, 4: 87-92.

Bouček, B., Münch, A. (1952): The Central European Retiolites of the Upper Wenlock and Ludlow. - Sborník Ústředního ústavu geologického, Oddíl paleontologický, 19: 1-151.

Burns, V., Rickards, R. B. (1993): Silurian graptolite faunas of the Balbriggan Inlier, counties Dublin and Meath, and their evolutionary, stratigraphical and structural significance. - Proceedings of the Yorkshire Geological Society, 49(4): 283-291.

https://doi.org/10.1144/pygs.49.4.283

Carruthers, W. (1867): Graptolites: their structure and systematic position. - Intellectual Observer, 11(4): 283-292. https://doi.org/10.1017/S0016756800171043

Elles, G. L. (1900): The zonal classification of the Wenlock Shales of the Welsh Borderland. - Quarterly Journal of the Geological Society, 56: 370-414. https://doi.org/10.1144/GSL.JGS.1900.056.01-04.25

Frech, F. (1897): Lethaea geognostica, I. Theil: Lethaea palaeozoica, 1. Band - E. Schweizerbartische Verlagshandlung, Stuttgart, $688 \mathrm{pp}$.

Geinitz, G. H. (1852): Die Versteinerungen der Grauwacken Formation (Die Graptolithen). - Wilhelm Engelmann, Leipzig, 58 pp.

Holm, G. (1890): Gotlands graptoliter. - Svenska vetenskap-akademie Handlingar, 16: 1-34.

Jaeger, H. (1991): Neue Standard-Graptolithenzonenfolge nach der „Grossen Krise“ an der Wenlock/Ludlow-Grenze (Silur). - Neues Jahrbuch für Geologie und Paläontologie, Abhandlungen, 182: 303-354.

https://doi.org/10.1127/njgpa/182/1991/303

Jaekel, O. (1889): Über das Alter des sogennanten Graptolithengesteins mit besonderer Berücksichtigung in demselben enthaltenen Graptolithen. - Zeitschrift der Deutschen geologischen Gesellschaft, 41: 653-690.

Jaworowski, K. (1965): Strop warstw posłęckich w obnażeniu litewskim a granica wenlok - ludlow [Top of the Pasłek Beds in the Lithuanian depression and the Wenlockian - Ludlowian boundary]. - Kwartalnik Geologiczny, 9: 511-526. (in Polish)

Jeppsson, L., Calner, M. (2003): The Silurian Mulde Event and a scenario for secundo-secundo events. - Transactions of the Royal Society of Edinburgh: Earth Sciences, 93: 135-154.

https://doi.org/10.1017/S0263593300000377

Kozłowska, A. (2015). Evolutionary history of the Gothograptus lineage of the Retiolitidae (Graptolithina).

- Estonian Journal of Earth Sciences, 64: 56-61. https://doi.org/10.3176/earth.2015.10

Kozłowska, A. (2016): A new generic name, Semigothograptus, for Gothograptus? meganassa Rickards and Palmer, 2002 from the Silurian post-lundgreni Biozone recovery phase, and comparative morphology of retiolitids from the lowermost upper Homerian (upper Wenlock). Zootaxa, 4208(6): 534-546.

https://doi.org/10.11646/zootaxa.4208.6.2
Kozłowska, A., Bates, D., Zalasiewicz, J., Radzevičius, S. (2019): Evolutionary significance of the retiolitine Gothograptus (Graptolithina) with four new species from the Silurian of the East European Platform (Baltica), Poland and Lithuania. - Zootaxa, 4568(3): 435-469. https://doi.org/10.11646/zootaxa.4568.3.2

Kozłowska-Dawidziuk, A. (1990): The genus Gothograptus (Graptolithina) from the Wenlock of Poland. - Acta Palaeontologica Polonica, 35: 191-209.

Kozłowska-Dawidziuk, A., Lenz, A. C., Štorch, P. (2001): Upper Wenlock and lower Ludlow (Silurian), post-extinction graptolites, Všeradice Section, Barrandian area, Czech Republic. - Journal of Paleontology, 75: 147-164. https://doi.org/10.1017/S0022336000031966

Kříž, J. (1992): Silurian Field Excursions: Prague Basin (Barrandian), Bohemia. - National Museum Wales, Geological Series, 13: 1-111.

Lenz, A. C. (1975): Silurian graptolites from Eastern Gaspé, Québec. - Canadian Journal of Earth Sciences, 12: 77-89. https://doi.org/10.1139/e75-009

Lenz, A. C., Melchin, M. J. (1990): Wenlock (Silurian) graptolite biostratigraphy of the Cape Phillips Formation, Canadian Arctic Islands. - Canadian Journal of Earth Sciences, 27: 1-13. https://doi.org/10.1139/e90-001

Lenz, A. C., Melchin, M. J. (1991): Wenlock (Silurian) graptolites, Cape Phillips Formation, Canadian Arctic Islands. - Transactions of the Royal Society of Edinburgh: Earth Sciences, 82: 211-237. https://doi.org/10.1017/S0263593300005320

Loydell, D. K. (1991): The biostratigraphy and formational relationships of the upper Aeronian and lower Telychian (Llandovery, Silurian) formations of western mid-Wales. - Geological Journal, 26: 209-244.

Loydell, D. K., Nestor, V., Männik, P. (2010): Integrated biostratigraphy of the lower Silurian of the Kolka-54 core, Latvia. - Geological Magazine, 147: 253-280. https://doi.org/10.1017/S0016756809990574

Maletz, J., Königshof, P., Meco, S., Schindler, E. (1998): Late Wenlock to Early Ludlow graptolites from Albania. - Senckenbergiana lethaea, 78: 141-151. https://doi.org/10.1007/BF03042765

Manda, Š., Štorch, P., Frýda, J., Slavík, L., Tasáryová, Z. (2019): The mid-Homerian (Silurian) biotic crisis in offshore settings of the Prague Synform, Czech Republic: integration of the graptolite fossil record with conodonts, shelly fauna and carbon isotope data. - Palaeogeography, Palaeoclimatology, Palaeoecology, 528: 14-34. https://doi.org/10.1016/j.palaeo.2019.04.026

Meneghini, N. (1857): Paleontologie de l'Ile de Sardaigne. - In: La Marmora, A. (ed.), Voyage en Sardaigne. Imprimaire Royal, Turin, Paris, 584 pp.

Münch, A. (1952): Die Graptolithen aus dem anstehenden Gotlandium Deutschlands und der Tschechoslowakei. Geologica, 7: 1-157.

Murchison, R. I. (1839): The Silurian System, founded on Silurian Researches in the counties of Salop, Hereford, Radnor, Montgomery, Caermarthen, Brecon, Pembroke, Monmouth, Gloucester, Worcester and Stafford: with descriptions of the Coalfields and overlying formations. - John Murray, London, 768 pp. https://doi.org/10.5962/bhl.title.88029 
Obut, A. M., Sennikov, N. V. (1977): Graptolity silura Chukotskogo poluostrova [Silurian graptolites of Chukotka Peninsula]. - In: Obut, A. M. (ed.), Stratigrafiya i fauna ordovika i silura Chukotskogo poluostrova [Stratigraphy and fauna of the Ordovician and Silurian of Chukotka Peninsula]. Izd. Nauka, Novosibirsk, pp. 103-145. (in Russian)

Palmer, D. C. (1970): Monograptus ludensis Zone graptolites from the Devilsbit Mountain District, Tipperary. - Scientific Proceedings of the Royal Dublin Society, Series A, 3: 335-342.

Přibyl, A. (1941): O několika nových druzích graptolitů z českého siluru [On several new graptolite species from the Silurian of Bohemia]. - Rozpravy 2. Tríidy České akademie, 51(7): 1-10. (in Czech)

Přibyl, A. (1943): Beitrag zur Kenntniss der Monograpten aus der Gruppe Monograptus flexilis. - Rozpravy 2. Tř́ídy České akademie, 52(5): 1-14.

Rickards, R. B. (1965): New Silurian graptolites from the Howgill Fells (Northern England). - Palaeontology, 8(2): 247-271.

Rickards, R. B., Palmer, D. C. (2002): Gothograptus? meganassa sp. nov., an unusually large retiolitid graptoloid from the late Wenlock ludensis Biozone of Long Mountain, Shropshire, UK. - Special Papers in Palaeontology, 67: 225-232.

Salter, J. W. (1852): Description of some graptolites from the south of Scotland. - Quarterly Journal of the Geological Society of London, 8: 1-5. https://doi.org/10.1144/GSL.JGS.1852.008.01-02.40

Štorch, P., Melchin, M. J. (2018): Lower Aeronian triangulate monograptids of the genus Demirastrites Eisel,
1912: biostratigraphy, palaeobiogeography, anagenetic changes and speciation. - Bulletin of Geosciences, 93(4): 513-537.

https://doi.org/10.3140/bull.geosci.1731

Štorch, P., Mitchell, C. E., Finney, S. C., Melchin, M. J. (2011): Uppermost Ordovician (upper Katian-Hirnantian) graptolites of north-central Nevada, USA. - Bulletin of Geosciences, 86(2): 301-386.

https://doi.org/10.3140/bull.geosci.1264

Teller, L. (1986): Morphology of selected Monograptidae from the Wenlock of NE Poland. - Palaeontographica, A, 192: 51-73.

Törnquist, S. L. (1910): Två Cyrtograptus-arter från Thüringen [Two species of Cyrtograptus from Thuringia]. - Geologiska Föreningens Förhandlingar, 32(7): 15591575. (in Swedish) https://doi.org/10.1080/11035891009443119

Tullberg, S. A. (1883): Skånes Graptoliter, 2 [Graptolites of Scania, 2]. - Sveriges geologiska Undersökning, Serie C, 55: 1-43. (in Swedish)

Turek, V. (1983): Hydrodynamic conditions and the benthic community of upper Wenlockian calcareous shales in the western part of the Barrandian (Kosov Quarry). - Časopis pro mineralogii a geologii, 28: 245-260.

Turek, V. (1990): Comments to upper Wenlock zonal subdivisions in the Silurian of Central Bohemia. - Casopis pro mineralogii a geologii, 35: 337-353.

Wood, E. M. R. (1900): The Lower Ludlow Formation and its graptolite fauna. - Quarterly Journal of the Geological Society of London, 56: 415-492. https://doi.org/10.1144/GSL.JGS.1900.056.01-04.26 